\title{
A 3-year prospective study of the incidence of gastric ulcers in pigs slaughtered at Base Abattoir in Rwanda
}

\author{
Borden Mushonga ${ }^{1}$, Bernard Yabaragiye ${ }^{2}$, Erick Kandiwa ${ }^{1}$, Gervais Habarugira² and Alaster Samkange ${ }^{3}$
}

1. Department of Biomedical Sciences, School of Veterinary Medicine, Faculty of Agriculture and Natural Resources, University of Namibia, P. Bag 13301, Pioneerspark, Windhoek, Namibia; 2. School of Animal Sciences and Veterinary Medicine, College of Agriculture, Animal Sciences and Veterinary Medicine, University of Rwanda, P. O. Box 57 Nyagatare, Rwanda; 3. Department of Veterinary Clinical Studies, School of Veterinary Medicine, Faculty of Agriculture and Natural Resources, University of Namibia, P. Bag 13301, Pioneerspark, Windhoek, Namibia. Corresponding author: Alaster Samkange, e-mail: alastersamkange@gmail.com

Co-authors: BM: bmushonga@unam.na, BY: yabaragiyeb@gmaill.com, EK: ekandiwa@unam.na, GH: gervaish@gmail.com Received: 08-04-2017, Accepted: 21-06-2017, Published online: 07-08-2017

doi: 10.14202/vetworld.2017.873-879 How to cite this article: Mushonga B, Yabaragiye B, Kandiwa E, Habarugira G, Samkange A (2017) A 3-year prospective study of the incidence of gastric ulcers in pigs slaughtered at Base Abattoir in Rwanda, Veterinary World, 10(8): 873-879.

\begin{abstract}
Aim: Determination of the incidence of gastric ulcers in pigs slaughtered at Base Abattoir in Rwanda.

Materials and Methods: Stomachs from all 5040 pigs that were slaughtered at Base Abattoir in Rwanda from August 2012 to August 2015 were examined for the presence and location of gastric ulcers. The results of the inspections were recorded and analyzed. Statistical analysis for Chi-square values was performed using the Software Package for Social Sciences version 16.0. The $\mathrm{Z}$ test for comparison of proportions was used and $\mathrm{p}<0.05$ was considered significant.

Results: Overall as well as per district, significantly more male pigs than female pigs were slaughtered $(\mathrm{p}<0.05)$. The incidence of gastric ulcers in slaughter pigs was $12.86 \%$. The incidence of gastric ulcers in males (13.36\%) was not significantly different $(\mathrm{p}>0.05)$ from that in female pigs $(12.84 \%)$ in all three districts. A significantly greater proportion of these ulcers $(69.03 \%)$ was located in the esophageal region than in the glandular region of the stomach (30.97\%) in slaughtered males $(\mathrm{p}<0.05)$. A significantly greater proportion of these ulcers $(79.59 \%)$ was located in the esophageal region than in the glandular region of the stomach $(20.41 \%)$ in slaughtered females $(\mathrm{p}<0.05)$. The overall incidence of esophageal ulcers $(9.44 \%)$ in the slaughtered pigs was significantly $(\mathrm{p}<0.05)$ higher than that of glandular region ulcers $(3.41 \%)$. Pigs with carcass weight over $60 \mathrm{~kg}$ showed a significantly $(\mathrm{p}<0.05)$ higher $(44.44 \%)$ incidence of ulcers than those between 40 and $60 \mathrm{~kg}(33.33 \%)$ and those below $40 \mathrm{~kg}(22.22 \%)$.
\end{abstract}

Conclusion: It was concluded that the incidence of gastric ulceration in slaughter pigs at Base Abattoir was not associated with source (district) or sex of pigs but was associated with the carcass weight.

Keywords: Base Abattoir, gastric ulcers, pigs, Rwanda.

\section{Introduction}

A gastric ulcer is a mucosal defect in which the entire epithelial thickness, down to or through the basement membrane has been lost [1]. The condition is quite common in man, dogs, cats' foals, cattle and is commonplace in pigs [1-3]. The problem is responsible for significant revenue losses in modern pig production enterprises [4-6]. Understanding the factors that influence the development of ulcers is therefore critical in designing management practices that minimize the development of ulcers in pigs [7].

Gastric ulceration in pigs has been observed and recorded as early as the mid 1940's [8]. Most research regards gastric ulcers as the most common pathological finding in the stomach of pigs at slaughter and thus

\footnotetext{
Copyright: Mushonga, et al. Open Access. This article is distributed under the terms of the Creative Commons Attribution 4.0 International License (http://creativecommons.org/licenses/ by/4.0/), which permits unrestricted use, distribution, and reproduction in any medium, provided you give appropriate credit to the original author(s) and the source, provide a link to the Creative Commons license, and indicate if changes were made. The Creative Commons Public Domain Dedication waiver (http:// creativecommons.org/publicdomain/zero/1.0/) applies to the data made available in this article, unless otherwise stated.
}

an important cause of sudden death from gastrointestinal bleeding in live pigs from some herds [7,9].

In pigs, ulceration can occur in the glandular and nonglandular (esophageal) parts of the stomach [7,10] although it occurs more commonly in the later (nonglandular or esophageal) region of the stomach $[7,11]$. On the other hand, ulceration of the glandular region, that is, the cardiac, fundic and pyloric regions [12] is regarded as less common and has normally been associated with systemic infections [13].

Several studies have evaluated the association between age, sex, and breed with the occurrence of gastric ulcers in pigs and no statistically significant findings were reported for age and sex although the problem was reported to be higher in sows than in finishing pigs [7] and higher in barrows than in gilts [10]. However, conflicting results have been reported for breed [7,14-17].

The prevalence of esophageal ulcers in finishing pigs varies widely across different studies, ranging from 2.3\% observed in Norway [18] to 5.1\% in South of Africa [19], and 6.4\% reported by other workers [20]. The prevalence figures as high as $15 \%$ have been reported in the last 20-25 years [9], and there is a 
general feeling that the prevalence of ulcers has been increasing over the same period [20]. More recently, the ulcer prevalence figures have been adopted as a measure of animal welfare standards [20,21]. The prevalence and economic impact of gastric ulceration in pigs of Rwanda are unknown.

Nutritional (dietary form), management, and infectious risk factors have been identified and studied extensively in relation to gastric ulcers $[22,23]$. The chief culprits among dietary forms that had a tendency to increase gastric ulceration were fine grinding [24], expansion, hydrothermal treatment and pelleting of feed $[7,25]$. According to Nguyen et al. [26], feeding crumbled feed may have an effect in reducing ulceration. Restricted feeding, large farm size, water quality, slatted floor type have featured prominently in literature as causes of gastric ulceration [24]. Holding pigs overnight before slaughter can also cause preslaughter stress which can also lead to the development of gastric ulcers [20]. However, reports of ambient temperatures have produced conflicting results. Supplying straw to pigs has been found to reduce the incidence of ulcers in pigs [21,27-29]. There are also conflicting reports on the association between growth performance and occurrence of gastric ulcers [30,31]. Many studies have reported a causative association between Helicobacter infections and gastric ulceration [24,32]. It has also been suggested that quality of water plays an important role in the causation of gastric ulcers and can act as a source of Helicobacter species or gastrospirillum [7,33]. Other factors that have also been mentioned include housing without litter and the use of nonsteroidal anti-inflammatory drugs (NSAIDs) [11].

Although the pathogenesis of gastric ulceration is known to be multifactorial and complex, it essentially involves a tilt in the balance between defensive factors and the buffering system resulting in prolonged activation of pepsinogens and changes in mucus composition $[10,24]$. Gastric acid production, pepsin, ethanol, bile salts, and drugs such as NSAIDs have all been identified as aggravating factors while the mucus-bicarbonate layer, prostaglandins, cellular degeneration and mucosal blood flow were identified as defensive factors [15]. It would appear that the production of urease by Helicobacter species results in the hydrolysis of urea to carbon dioxide and ammonia. Ammonia then neutralizes the acidity in the stomach and allows colonization of gastric mucosa by the bacteria [23] Urease also abates the inflammatory processes that result in the development of gastric ulcers [31]. Ulcer complications can include perforations leading to severe peritonitis, blood loss, and even death [34].

Deaths occur mostly at the grower-finisher stage and have always had a significant economic impact on operations $[4,9]$. Different researchers have documented contradictory evidence on the impact of gastric ulceration on live weight gain of pigs [35-37]. However, the cross-sectional nature of these studies precludes a proper interpretation of the temporal relationships between these phenomena. Economics and welfare concerns justify the monitoring of pig populations to determine the prevalence and severity of these stomach lesions [4].

A number of techniques including postmortem examination of abattoir specimens by gross inspection [38] as well as by histology [31], endoscopy [30], gastrocamera photography [39], and clinical biochemistry have been used in the diagnosis of gastric ulcers in pigs.

S-methylmethionine sulfonium chloride has been used at $200 \mathrm{mg} / \mathrm{kg}$ for supplementation and as prevention or therapy for esophagogastric ulcers in pigs with no significant benefits [39]. The efficacy of melatonin in the treatment of gastric ulcers in pigs has also been demonstrated [40]. There are no commercially viable treatments for commercial pigs although proton pump inhibitors can be used in pet pigs and very valuable breeding animals [41].

According to Monteiro [7], management strategies to prevent ulceration in pigs require an in-depth understanding of the nutritional and management factors involved in the etiopathogenesis of gastric ulceration in pigs.

The aim of this study was to explore gastric ulceration and associated factors in slaughter pigs from three districts of Northern Rwanda.

\section{Materials and Methods}

\section{Ethical approval}

Since only abattoir samples were used for the study, ethical approval was therefore not necessary for this kind of the study.

\section{Study area}

The study was conducted at Base Abattoir located in Rulindo district, in the Northern Province of Rwanda. The owners of the abattoir were notified of the aims, scope, duration, and procedures of this study and provided the researchers with written consent before its commencement. The abattoir's catchment area exclusively includes Rulindo, Gicumbi, and Kicukiro districts. During the duration of the study, the abattoir slaughtered 612, 1404 and 3024 pigs from Gicumbi, Kicukiro and Rulindo districts, respectively. In the course of the study, the researchers visited randomly selected pig farms in the three districts in order to familiarize themselves with the scale of operations and the husbandry practices of the farmers. Pig farming in these districts was primarily practiced by smallholder farmers.

\section{Inspection at abattoir}

A 3-year prospective study was done on all 5040 pigs slaughtered at Base Abattoir from August 2012 to August 2015. The breeds of pigs slaughtered were of the Large White, Landrace and Landrace-Large white cross varieties. Ethical slaughter process was carried out in the usual format of evisceration, splitting, washing followed by postmortem inspection. The stomachs 
of all animals were opened along the greater curvature using a pair of scissors, emptied, washed with running tap water and then inverted to allow visual inspection of the gastric mucosa by veterinary pathologists in the research team. The presence and location (esophageal or glandular) of gastric ulcers were noted and recorded.

\section{Statistical analysis}

Statistical analysis for Chi-square values was performed using the Software Package for Social Sciences version 16.0. The $\mathrm{Z}$ test for comparison of proportions was used and $\mathrm{p}<0.05$ was considered significant.

\section{Results}

There was a significant difference $(p<0.05)$ between the total numbers of female and male pigs which were slaughtered at Rulindo abattoir (Table-1), with more males slaughtered than females.

There was no significant difference $(\mathrm{p}>0.05)$ in the incidence of gastric ulcers between male and female pigs that were slaughtered (Tables-2 and 3).

In male pigs, there was a significant difference in the location of the gastric ulcers $(p<0.05)$; there were more ulcers in the esophageal region compared to the glandular region (Table-4). The picture was the same for females pigs (Table-5).

In total, there were significantly more $(\mathrm{p}<0.05)$ esophageal ulcers than glandular ulcers (Table-6).

The incidence of esophageal region ulcers in the $>60 \mathrm{~kg}$ category was significantly higher than that in the $40-60 \mathrm{~kg}$ category $(\mathrm{p}<0.05)$, which in turn was significantly higher than that in $<40 \mathrm{~kg}$ category $(\mathrm{p}<0.05)$ (Table-7).
The results in Table- 8 illustrate the distribution of pig gastric and esophageal ulcers across weight categories at slaughter. Statistical analysis of the results in Table- 8 using cross-tabulated $\mathrm{Z}$ scores and $\mathrm{p}$ values showed that the incidence of glandular region ulcers in the $>60 \mathrm{~kg}$ category was significantly higher than that in the 40-60 kg category $(\mathrm{p}<0.05)$ which in turn was significantly higher than that in $<40 \mathrm{~kg}$ category $(p<0.05)$. Overall, the incidence of gastric ulcers in the $>60 \mathrm{~kg}$ category was significantly higher than that in the 40-60 kg category $(\mathrm{p}<0.05)$ which in turn was significantly higher than that in $<40 \mathrm{~kg}$ category $(\mathrm{p}<0.05)$.

\section{Discussion}

An overall incidence of porcine gastric esophageal ulcers of $9.44 \%$ in this study was higher than the incidence recorded in other African studies $[19,42]$. However, a much higher percentage was reported in Canada (15.5\%), USA (16.4\%), Portugal (18.7\%), United Kingdom (19.6\%), and Australia (31\%) $[7,9,36,37,39,43]$. The overall occurrence of porcine gastric glandular ulcers of $3.41 \%$ in this study appears to show an increase from the $0.19 \%$ observed in the $1970 \mathrm{~s}$ [44], the $1.2 \%$ recorded in the early 60's [45], and the $2.1 \%$ recorded in the 70's [45]. However, there was also another study in which incidences ranging from $12 \%$ to $29 \%$ were also reported [46]. It is tempting to conclude that the $3.41 \%$ occurrence figure, shown by our study, is a reflection of an upward trend reported by previous workers $[44,45]$. The fact that pig feed processing techniques have achieved progressively smaller particle sizes over the past four decades suggests that pigs

Table-1: Total number of pigs that were slaughtered at Base Abattoir categorized according to district of origin and sex.

\begin{tabular}{lccccc}
\hline District & Male pigs slaughtered & Female pigs slaughtered & Total & Proportion (\%) & p value \\
\hline Gicumbi & 396 & 216 & 612 & 12.14 & $0.00 *$ \\
Kicukiro & 1080 & 324 & 1404 & 27.86 & $0.00 *$ \\
Rulindo & 1908 & 1116 & 3024 & 60.00 & $0.00 *$ \\
Total & 3384 & 1656 & 5040 & 100.00 & - \\
\hline
\end{tabular}

*Significant difference between number of males and females slaughtered $(p<0.05)$

Table-2: Occurrence of gastric ulcers in slaughtered pigs according to district and sex.

\begin{tabular}{lccc}
\hline District & $\begin{array}{c}\text { Male pigs with gastric } \\
\text { ulcers }\end{array}$ & $\begin{array}{c}\text { Female pigs with gastric } \\
\text { ulcers }\end{array}$ & $\begin{array}{c}\text { Total number of pigs with } \\
\text { ulcers }\end{array}$ \\
\hline Gicumbi & 76 & 32 & $0.50^{\#}$ \\
Kicukiro & 124 & 56 & 108 \\
Rulindo & 252 & 108 & 180 \\
Total & 452 & 196 & 360 \\
\hline
\end{tabular}

\#No significant difference in the occurrence of gastric ulcers between male and female pigs ( $p>0.05)$

Table-3: Overall occurrence of gastric ulcers in slaughtered pigs according to sex.

\begin{tabular}{lcccc}
\hline District & $\begin{array}{c}\text { Slaughtered pigs with gastric } \\
\text { ulcers }\end{array}$ & $\begin{array}{c}\text { Slaughtered pigs without gastric } \\
\text { ulcers }\end{array}$ & $\begin{array}{c}\text { Proportion of pigs with } \\
\text { gastric ulcers (\%) }\end{array}$ & $\begin{array}{c}\text { Total } \\
\text { (\%) }\end{array}$ \\
\hline Male pigs & 452 & 2932 & 13.36 & 3384 \\
Female pigs & 196 & 1460 & 11.84 & 1656 \\
Total & 648 & 4392 & 12.86 & 5040 \\
\hline
\end{tabular}


have been at progressively higher risk for ulceration over the same period. There have been suggestions that technology and industrialization which have seen an increase from the 60's to the 80 's may be responsible for the concomitant rise in ulceration in pigs [7].

The ulcers in glandular region have been associated with systemic diseases such as salmonellosis, erysipelas or hog cholera infections $[45,47]$. The first possible explanation of higher occurrence of glandular ulcers in this study was the relatively low availability (and even total lack) of veterinary services and disease control in the three districts that provided animals slaughtered at Base Abattoir. The second possible explanation was the poor level of hygiene resulting from lack of clean water sources and inadequate waste disposal facilities observed in most farms visited in the course of the study. In an earlier study in Australia,

Table-4: Occurrence of esophageal and glandular gastric ulcers in slaughtered male pigs according to district.

\begin{tabular}{lcccc}
\hline District & $\begin{array}{c}\text { Ulcers in } \\
\text { esophageal } \\
\text { region }\end{array}$ & $\begin{array}{c}\text { Ulcers in } \\
\text { glandular } \\
\text { region }\end{array}$ & Total & p value \\
\hline Gicumbi & 60 & 16 & 76 & $0.01^{*}$ \\
Kicukiro & 84 & 40 & 124 & $0.05^{*}$ \\
Rulindo & 176 & 76 & 252 & $0.00^{*}$ \\
Total & 312 & 140 & 452 & $0.00^{*}$ \\
\hline
\end{tabular}

*Significant difference in the location of gastric ulcers $(p<0.05)$

Table-5: Occurrence of esophageal and glandular gastric ulcers in slaughtered female pigs according to district.

\begin{tabular}{lcccc}
\hline District & $\begin{array}{c}\text { Ulcers in } \\
\text { esophageal } \\
\text { region }\end{array}$ & $\begin{array}{c}\text { Ulcers in } \\
\text { glandular } \\
\text { region }\end{array}$ & $\begin{array}{c}\text { Total number p value } \\
\text { of female } \\
\text { pigs with } \\
\text { ulcers }\end{array}$ & \\
\hline Gicumbi & 28 & 4 & 32 & $0.03^{*}$ \\
Kicukiro & 44 & 12 & 56 & $0.03^{*}$ \\
Rulindo & 84 & 24 & 108 & $0.00^{*}$ \\
Total & 156 & 40 & 196 & $0.00^{*}$ \\
\hline
\end{tabular}

*Significant difference in the location of gastric ulcers $(p<0.05)$ animals receiving dam water had a higher prevalence of esophageal gastric ulcers than those from farms using water from a borehole [37]. These Australian researchers blamed high levels of bacteria for reduced water quality resulting in bacterial infections predisposing animals to esophageal gastric ulcers [37]. As in humans, the colonization of the stomach by organisms of the Helicobacter-type was suggestively connected with the development of gastric ulcers in pigs $[14,33,48-50]$. The third observation made by the authors on visiting sample pig farms in the three districts was a realization that piggeries in Kicukiro and Rulindo were much larger operations but without corresponding improvements in clean water supply, husbandry techniques and facilities.

The significant variation in the occurrence of esophageal gastric ulcers between districts was indicative of the predisposing factors of the district of origin. A similar pattern was reported in Portugal showing significant differences in the occurrence of esophageal gastric ulcers between nine different farms under the study [7]. In one study, significant differences in the percentage of gastric ulcers between two farms were demonstrated [45]. Differences in the prevalence of esophageal gastric ulcers between herds and in distinct Australian states were also observed [37]. The prevalence of esophageal gastric ulcers in Victoria (53\%) was significantly higher than in Western Australia (30\%) or Queensland $(7 \%)$. Large herd sizes and their negative impact on management and nutritional practices were cited as possible causative factors for such a pattern. This study noticed the same trend whereby farmers increased herd sizes so as to increase incomes without necessarily improving husbandry facilities and practices.

Findings of no significant difference in the frequency of esophageal gastric ulcers between males and females in this study were supported by findings from other studies [35,37,51]. The risk factors associated with the occurrence of gastric ulcers have been largely documented and evaluated [4,37]. This

Table-6: Overall occurrence of esophageal and glandular gastric ulcers according to district.

\begin{tabular}{|c|c|c|c|c|c|}
\hline District & $\begin{array}{c}\text { Ulcers in } \\
\text { esophageal region }\end{array}$ & $\begin{array}{l}\text { Proportion of ulcers in } \\
\text { slaughtered population }(\%)\end{array}$ & $\begin{array}{l}\text { Ulcers in } \\
\text { glandular region }\end{array}$ & $\begin{array}{l}\text { Proportion of ulcers } \\
\text { in slaughtered } \\
\text { population }(\%)\end{array}$ & p value \\
\hline Gicumbi & 88 & 1.74 & 20 & 0.40 & $0.03 *$ \\
\hline Kicukiro & 128 & 2.54 & 52 & 1.03 & $0.03 *$ \\
\hline Rulindo & 260 & 5.16 & 100 & 1.98 & $0.00 *$ \\
\hline Total & 476 & 9.44 & 172 & 3.41 & $0.00 *$ \\
\hline
\end{tabular}

*Significant difference in occurrence of esophageal and glandular region gastric ulcers $(p<0.05)$

Table-7: Location of pig gastric ulcers according to carcass weight category.

\begin{tabular}{lcccc}
\hline $\begin{array}{l}\text { Carcass weight } \\
\text { category }\end{array}$ & $\begin{array}{c}\text { Pigs with esophageal } \\
\text { region ulcers }\end{array}$ & $\begin{array}{c}\text { Pigs with glandular } \\
\text { region ulcers }\end{array}$ & $\begin{array}{c}\text { Total number of } \\
\text { male pigs with ulcers }\end{array}$ & $\begin{array}{c}\text { Proportion of pigs } \\
\text { with ulcers (\%) }\end{array}$ \\
\hline$<40 \mathrm{~kg}$ & 112 & 32 & 144 & 22.22 \\
$40-60 \mathrm{~kg}$ & 160 & 56 & 216 & 33.33 \\
$>60 \mathrm{~kg}$ & 196 & 92 & 288 & 44.44 \\
Total & 468 & 180 & 648 & 100.00 \\
\hline
\end{tabular}


Table-8: Distribution of pig ulcers according to weight categories.

\begin{tabular}{lcccc}
\hline Categories of lesions & $\mathbf{4 0} \mathbf{~ k g ~ c a t e g o r y ~}$ & $\mathbf{4 0 - 6 0} \mathbf{~ k g ~ c a t e g o r y}$ & $\mathbf{~ 6 0} \mathbf{~ k g}$ category & Grand total \\
\hline Pigs with esophageal ulcers & 112 & 160 & 196 & 468 \\
Pigs without esophageal ulcers & 2021 & 1440 & 1111 & 4572 \\
Category total & 2133 & 1600 & 1307 & 5040 \\
Pigs with glandular region ulcers & 32 & 56 & 1215 & 180 \\
Pigs without glandular region ulcers & 2101 & 1544 & 1307 & 4860 \\
Category total & 2133 & & & 5040 \\
\hline
\end{tabular}

study noted that the main risk factors associated with the occurrence of gastric ulcers in pigs were water, diet (main and supplement food), and hygiene (waste management).

Feeding pigs with finely ground feeds was associated with a higher incidence of ulcers in such herds [52-54]. Other studies showed feeding pigs with pelleted feeds was also associated with a higher incidence of ulcers $[10,18,24,43,54,55,56]$. Feed restriction for economic reasons or as a feeding practice was suggested as a possible stress factor resulting from lower dietary fiber and resulting in gastric ulceration in some studies [37]. Breed was also shown as a predisposing factor in the incidence of porcine gastric ulcers when a higher incidence of ulcers (29\%) in the Duroc breed was compared to the lower incidence $(12 \%)$ in the Yorkshire breed [46]. Other studies did not yield consistent results to prove such an association between genetic background and gastric ulcers $[35,47,54]$.

\section{Authors' Contributions}

BM contributed in designing of the study, supervision of the project, and writing of the final version of the manuscript. BY did the administration of the survey, collection and examination of abattoir samples and writing of the draft manuscript. EK did the designing of the experiment, the statistical analysis and the final manuscript write up and editing. GH did the data analysis, the write up of the draft and editing of the final version of the manuscript. AS did the designing of the studies, write-up of the draft, editing the final version and coordinated the publication of this manuscript. All authors read and approved the final manuscript.

\section{Acknowledgments}

The authors are grateful to the authorities of former Umutara Polytechnic (now University of Rwanda), for providing the facilities and financial grant \# UPRC/22/2011 assistance to carry out this work.

\section{Competing Interests} interests.

The authors declare that they have no competing

\section{References}

1. Gelberg, H.B. (2012) Alimentary system and the peritoneum, omentum, mesentery, and peritoneal cavity. In:
Pathologic Basis of Veterinary Disease. Mosby, St. Louis. p326-327.

2. Majekodunmi, M., Omotosho, O., Emikpe, B., Olufemi, B. and Olufemi, B. (2013) The incidence of gastric lesions in slaughtered pigs in Ibadan, Nigeria. Sokoto J. Vet. Sci., 11: 22-77.

3. Mishra, S.K., Mishra, V., Pandey, A.K. and Srivastava, A. (2014) Docking study of the rohitukine for the prevention of peptic ulcer - A new target. J. Phytopharm., 3: 9-15.

4. Friendship, R.M. (2004) Gastric ulceration in swine. J. Swine Health Prod., 12: 34-35.

5. Friendship, R.M. (2006) Gastric ulcers. In: Diseases of Swine. $9^{\text {th }}$ ed. Blackwell Publishing, Ames, Iowa. p891-899.

6. Omotosho, O.O., Emikpe, B.O., Lasisi, O.T. and Jarikre, T.A. (2016) Prevalence, distribution and pattern of gastric lesions in slaughtered pigs in South-Western Nigeria. Onderstepoort J. Vet. Res., 83: 6.

7. Monteiro, S.D.A. (2011) Prevalence and Risk Factors for Gastrics Ulcers in Swine. Faculdade de Medicina da Universidade do Porto FMUP, São Paulo, Brazil.

8. Kernkamp, H.C. (1945) Gastric ulcer in swine. Am. J. Pathol., 21: 111-113.

9. Melnichouk, S.I. (2002) Mortality associated with gastric ulceration in swine. Can. Vet. J., 43: 223-225.

10. Canibe, N., Blaabjerg, K. and Lauridsen, C. (2016) Gastric Ulcers in Pigs. Available from: http://www.pure.au.dk/ portal/files/108305983/Vidensyntese_Gastric_ulcers_in_ pigs_231216.pdf.

11. Mößeler, A., Köttendorf, S., Liesner, V.G. and Kamphues, J. (2010) Impact of diets' physical form (particle size; meal/pelleted) on the stomach content (dry matter content, $\mathrm{pH}$, chloride concentration) of pigs. Livest. Sci., 134: 146-148.

12. Zalecki, M. (2015) The influence of antral ulcers on intramural gastric nerve projections supplying the pyloric sphincter in the pig (Sus scrofa domestica) - Neuronal tracing studies. PLoS One, 10: 1-11.

13. Friendship, R. (1999) Gastric ulcers. In: Diseases of Swine. Iowa State University, Ames, IA, USA. p685-694.

14. Appino, S., Guarda, F., Pregel, P., Amedeo, S., Cutufia, M. and Bellonio, G. (2006) Detection of helicobacter candidatus suis by PCR in oesophagogastric ulcers of swine in Italy. Acta Vet. Hung., 54: 517-524.

15. Prabhu, V. and Shivani, A. (2014) An overview of history, pathogenesis and treatment of perforated peptic ulcer disease with evaluation of prognostic scoring in adults. Ann. Med. Health Sci. Res., 4: 22-29.

16. Paulk, C.B., Hancock, J.D., Fahrenholz, A.C., Wilson, J.M., McKinney, L.J. and Benhke, K.C. (2015) Effects of feeding cracked corn to nursery and finishing pigs. J. Anim. Sci., 93: 1710-1720.

17. Rojas, O.J., Liu, Y. and Stein, H.H. (2016) Effects of particle size of yellow dent corn on physical characteristics of diets and growth performance and carcass characteristics of growing-finishing pigs. J. Anim. Sci., 94: 619-628.

18. Flatlandsmo, K. and Slagsvold, P. (1971) Effect of grain particle size and pellets on development of gastric ulcers in swine. J. Anim. Sci., 33: 1263.

19. Makinde, M. and Gous, T. (1998) Prevalence of gastro-oesophageal ulcers in grower-finisher pigs in the 
Northern Province of South Africa: Research communication. J. S. Afr. Vet., 69: 59-60.

20. Swaby, H. and Gregory, N.G. (2012) A note on the frequency of gastric ulcers detected during post-mortem examination at a pig abattoir. Meat Sci., 90: 269-271.

21. Pedersen, L.J., Herskin, M.S., Forkman, B., Elvang, H. and Margit, J. (2015) Increasing amounts of straw increase growing pigs production and health. In: International Conference on Pig Welfare: Improving Pig Welfare - What are the Ways forward?. p98.

22. Millet, S., Kumar, S., De Boever, J., Ducatelle, R. and De Brabander, D. (2012) Effect of feed processing on growth performance and gastric mucosa integrity in pigs from weaning until slaughter. Anim. Feed Sci. Technol., 75: $175-181$.

23. Millet, S., Kumar, S., De Boever, J., Meyns, T., Aluwé, M. and De Brabander, D. (2012) Effect of particle size distribution and dietary crude fibre content on growth performance and gastric mucosa integrity of growing-finishing pigs. Vet. J., 192: 316-321.

24. Steenkamp, J.A. (2014) The Evaluation of the Effect of Acid Buf on Stomach Ulcer Occurrence, Growth Performance and Histological Parameters of Grower - Finisher Pigs. Thesis, Stellenbosch University.

25. Liermann, W., Berk, A., Böschen, V. and Dänicke, S. (2015) Effects of particle size and hydro-thermal treatment of feed on performance and stomach health in fattening pigs. Arch. Anim. Nutr., 69: 455-472.

26. Nguyen, D.H., Park, J.W. and Kim, I.H. (2016) Effect of crumbled diet on growth performance, market day age and meat quality of growing-finishing pigs. J. Appl. Anim. Res., 45: 396-399.

27. Di Martino, G., Capello, K, Scollo, A., Gottardo, F., Stefani, A.L. and Rampin, F. (2013) Continuous straw provision reduces prevalence of oesophago-gastric ulcer in pigs slaughtered at $170 \mathrm{~kg}$ (heavy pigs). Res. Vet. Sci., 95: 1271-1273.

28. Herskin, M.S., Jensen, H.E., Jespersen, A., Forkman, B., Jensen, M.B. and Canibe, N. (2016) Impact of the amount of straw provided to pigs kept in intensive production conditions on the occurrence and severity of gastric ulceration at slaughter. Res. Vet. Sci., 104: 200-206.

29. Jensen, K.H., Jørgensen, L., Haugegaard, S., Herskin, M.S., Jensen, M.B. and Pedersen, L.J. (2017) The dose-response relationship between the amount of straw provided on the floor and gastric ulceration of pars oesophagea in growing pigs. Res. Vet. Sci., 112: 66-74.

30. Ayles, H.L., Friendship, R.M. and Ball, R.O. (1996) Effect of dietary particle size on gastric ulcers, assessed by endoscopic examination, and relationship between ulcer severity and growth performance of individually fed pigs. Swine Heal. Prod., 4(5): 211-216.

31. Haesebrouck, F., Pasmans, F., Flahou, B., Chiers, K., Baele, M. and Meyns, T. (2009) Gastric Helicobacters in domestic animals and nonhuman primates and their significance for human health. Clin. Microbiol. Rev., 22: 202-223.

32. Baele, M., Decostere, A., Vandamme, P., Ceelen, L., Hellemans, A. and Mast, J. (2008) Isolation and characterization of Helicobacter suis sp. Nov. from pig stomachs. Int. J Syst. Evol. Microbiol., 58: 1350-1358.

33. Barbosa, A.J.A., Silva, J.C.P., Nogueira, A.M.M., Paulino, E. and Miranda, C.R. (1995) Higher incidence of Gastrospirillum sp. in swine with gastric ulcer of the pars oesophagea. Vet. Pathol., 32: 134-139.

34. Sumiyama, K., Gostout, C.J., Rajan, E., Bakken, T.A., Deters, J.L. and Knipschield, M.A. (2007) Endoscopic full-thickness closure of large gastric perforations by use of tissue anchors. Gastrointest. Endosc., 65: 134-139.

35. Elbers, A.R., Hessing, M.J., Tielen, M.J. and Vos, J.H. (1995) Growth and oesophagogastric lesions in finishing pigs offered pelleted feed ad libitum. Vet. Rec., 36: 588-590.

36. Eisemann, J.H., Morrow, W.E.M., See, M.T., Davies, P.R. and Zering, K. (2002) Effect of feed withdrawal prior to slaughter on prevalence of gastric ulcers in pigs. J. Am. Vet. Med. Assoc., 220: 503-506.

37. Robertson, I.D., Accioly, J.M., Moore, K.M., Driesen, S.J., Pethick, D.W. and Hampson, D.J. (2002) Risk factors for gastric ulcers in Australian pigs at slaughter. Prev. Vet. Med., 53: 293-303.

38. Grosse, L.V., Taube, V., Leonhard-Marek, S., Beineke, A. and Kamphues, J. (2009) Integrity of gastric mucosa in reared piglets - Effects of physical form of diets (meal/ pellets), pre-processing grinding (coarse/fine) and addition of lignocellulose (0/2.5\%). J. Anim. Physiol. Anim. Nutr., 93: 373-380.

39. Kopinski, J.S., Fogarty, R. and McVeigh, J. (2007) Effect of S-methylmethionine sulphonium chloride on oesophagogastric ulcers in pigs. Aust. Vet. J., 85: 362-367.

40. Bubenik, G.A. (2008) Thirty four years since the discovery of gastrointestinal melatonin. J. Physiol. Pharmacol., 59: 33-51.

41. Friendship, R.M. (2016) Gastric ulcers in pigs. In: The Merck Veterinary Manual. 11 th ed. Available from: http:// www.msdvetmanual.com/digestive-system/gastrointestinal-ulcers-in-large-animals/gastric-ulcers-in-pigs. Last Accessed on 06-12-2016.

42. Banga-Mboko, H., Tamboura, H., Maes, D., Traoré, H., Youssao, I. and Sangild, P.T. (2003) Survey of gastric lesions and blood pepsinogen levels in pigs in Burkina Faso. Vet. Res. Commun., 27: 595-602.

43. Amory, J.R., Mackenzie, A.M. and Pearce, G.P. (1974) Factors in the housing environment of finisher pigs associated with the development of gastric ulcers. Vet. Rec., 158: 260-264.

44. Bivin, W.S., De Barros, C.L. and De Barros, S.S. (1974) Gastric ulcers in Brazilian swine. J. Am. Vet. Med. Assoc., 164: 405-407.

45. Muggenburg, B.A., Mcnutt, S.H. and Kowalczyk, T. (1964) Pathology of gastric ulcers in swine. Am. J. Vet. Res., 25: $1354-1365$.

46. Berruecos, J.M. and Robison, O.W. (1972) Inheritance of gastric ulcers in swine. J. Anim. Sci., 35: 20.

47. Curtin, T.M., Goetsch, G.D. and Hollandbeck, R. (1963) Clinical and pathologic characterization of esophagogastric ulcers in swine. J. Am. Vet. Med. Assoc., 143: 854-860.

48. Choi, Y.K., Han, J.H. and Joo, H.S. (2001) Identification of novel Helicobacter species in pig stomachs by PCR and partial sequencing. J. Clin. Microbiol., 39: 3311-3315.

49. Queiroz, D.M., Rocha, G.A., Mendes, E.N., De Moura, S.B., De Oliveira, A.M. and Miranda, D. (1996) Association between Helicobacter and gastric ulcer disease of the pars esophagea in swine. Gastroenterology, 111: 19-27.

50. Roosendaal, R., Vos, J.H., Roumen, T., van Vugt, R., Cattoli, G. and Bart, A. (2000) Slaughter pigs are commonly infected by closely related but distinct gastric ulcerative lesion-inducing gastrospirilla. J. Clin. Microbiol., 38: 2661-2664.

51. Guise, H.J., Carlyle, W.W., Penny, R.H., Abbott, T.A., Riches, H.L. and Hunter, E.J. (1997) Gastric ulcers in finishing pigs: Their prevalence and failure to influence growth rate. Vet. Rec., 141: 563-566.

52. Dobson, K.J., Davies, R.L. and Cargill, C.F. (1978) Ulceration of the pars oesophagia in pigs. Aust. Vet. J., 54: 601-602.

53. Lawrence, B.V., Anderson, D.B., Adeola, O. and Cline, T.R. (1998) Changes in pars esophageal tissue appearance of the porcine stomach in response to transportation, feed deprivation, and diet composition. J. Anim. Sci., 76: 788.

54. Mahan, D.C., Pickett, R.A., Perry, T.W., Curtin, T.M., Featherston, W.R. and Beeson, W.M. (1966) Influence of various nutritional factors and physical form of feed on esophagogastric ulcers in swine. J. Anim. Sci., 25: 1019-1023.

55. De Jong, J.A., De Rouchey, J.M., Tokach, M.D., Dritz, S.S., 
Goodband, R.D. and Woodworth, J.C. (2016) Evaluating pellet and meal feeding regimens on finishing pig performance, stomach morphology, and carcass characteristics. Kansas Agric. Exp. Stn. Res. Rep., 94: 4781-4788.

56. Overholt, M.F., Lowell, J.E., Arkfeld, E.K., Grossman, I.M.,
Stein, H.H. and Dilger, A.C. (2016) Effects of pelleting diets without or with distillers' dried grains with solubles on growth performance, carcass characteristics, and gastrointestinal weights of growing-finishing barrows and gilts. J. Anim. Sci., 94: 2172-2183.

$* * * * * * * *$ 